\section{LETTERS TO THE EDITOR}

\section{Chronic lymphocytic gastritis}

SIR, - We read with interest the article by Crampton et al on 'Chronic lymphocytic gastritis and protein losing gastropathy.' We are currently reviewing the clinical data of a large series of patients with the diagnosis of chronic lymphocytic gastritis (CLG), collected over the past six years.

We would like to add some comments from our own experience of the association between CLG and protein losing enteropathies. We collected clinical and laboratory data from 160 patients. Eighteen had lower limb oedema, which in 14 cases was of cardiac or renal origin or was related to prolonged venous stasis. However, in the other four patients, who had hypoproteinaemia as did Crampton's cases, no cause outside of the gastrointestinal tract was found to account for the protein loss. Ninety seven of the 160 patients of this series had complete biochemical investigations. Interestingly, $18(18 \%)$ had abnormal serum protein concentrations, lower than the lower limit of normal by at least $10 \%$. This may be related to the common observation that the enlarged gastric folds, characteristic of the varioliform features of the disease, are covered by a thick coat of mucus and crossed by large serpiginous erosions. $^{2}$

We published a series of 44 patients with CLG in $1986^{3}$ where weight loss and anorexia, also described by Crampton et al in their patients, were considered to be common symptoms. Indeed, $66 \%$ of patients presented with weight loss and $33 \%$ with anorexia. These symptoms were sufficiently severe in some cases to mimic clinically the presentation of gastric cancer and particularly, because of the enlarged rugal folds, gastric lymphoma.

Possible confusion with Menetrier's disease must be borne in mind. In fact, some of our patients carried the clinical and radiological diagnosis of Menetrier's disease. Furthermore, in one patient who came to surgery suffering from protein loss and peripheral oedema there was a complex pathological picture, with features of both CLG and Menetrier's disease, almost suggesting a relation between the two conditions. Leaving aside the debate concerning the infantile form of Menetrier's disease, it must be said that it shares clinical features with CLG, and like CLG can resolve spontaneously over a few months. B WEYNAND A JOURET-MOURIN Service d'Anatomie Pathologique, Cliniques Universitaires Saint Luc, Avenue Hippocrate 10 , Avenue Hippocrate 10,
1200 Bruxelles, Belgique

1 Crampton JR, Hunter JO, Neale G, Wight DGD. Chronic lymphocytic gastritis and protein losing gastropathy. Gut Festschrift 1989; 30: 71-4.

2 Haot J, Hamichi L, Wallez L, Mainguet P. Lymphocytic gastritis: a newly described entity. Lymphocytic gastritis: a newly described entity.
A retrospective endoscopic and histological A retrospective endoscopic
study. Gut 1988; 29: 1258-4.

3 Haot J, Jouret-Mourin A, Delos M, et al. Anatomoclinical study of a series of chronic gastritis characterized by intra-epithelíal lymphocytic characterized by intra-epithelial lymphocytic 4 Delos M, Jouret-Mourin A, Wallez L, Willette M Mainguet $P$, Haot $J$. Histological follow-up of series of gastritis characterized by intra-epithelia lymphocytic infiltration. Acta Endoscopica 1986; 16: 185-7.

\title{
Goblet cell carcinoid of the appendix
}

SIR, - The article by Park et al on 'Goblet cell carcinoid of the appendix' (Gut 1990; 31: 3224) is interesting, but the results presented do not justify their recommendation that all such patients should be treated by a right hemicolectomy. Four of the patients are alive and free of recurrent disease after appendicectomy. One of the patients treated by right hemicolectomy is dead. In only one patient was residual tumour found in the caecum and appendiceal stump and his follow up is only two months. Only one patient has presented late after appendicectomy with recurrent disease. This was 15 years after the original surgery and we are not told how long after his right hemicolectomy his current follow up is. It seems more sensible to recommend hemicolectomy for patients in whom the tumour is close to the base of the appendix, but the case for routine right hemicolectomy has not been substantiated in this paper.

\section{J A R SMITH Sheffield S5 $7 \mathrm{AU}$}

\section{Reply}

SIR, - We would agree that many patients with goblet cell carcinoid of the appendix appear to do well after simple appendicectomy. This tumour, however, has a more sinister prognosis than is generally accepted for carcinoid tumours. In our study the five year actuarial survival was $60 \%$ and in a review of published reports $16 \%$ of all cases had recurrence.' As stressed in our original article it is not possible to predict the behaviour on histological criteria, including position of the tumour. Of the four patients in our study with recurrent disease, two had proximal and two had distally situated tumours. Until better prognostic factors are identified, we think that a right hemicolectomy offers the best chance of preventing recurrence in otherwise healthy patients.

$$
\begin{array}{r}
\text { K PARK } \\
\text { K BLESSING } \\
\text { K KERR } \\
\text { U CHETTY } \\
\text { H GILMOUR } \\
\text { Deparment of Surgery, } \\
\text { University Medical Building, } \\
\text { Foresterhill, }
\end{array}
$$

1 Edmonds P, Merino MJ, Livolsi VA, Duray PH. Adenocarcinoids (mucinous carcinoid) of the Adenocarcinoids (mucinous carcinoid) of
appendix. Gastroenterology 1984; 86: 302-9.

\section{One minute urease test}

SIR, - After setting up the one minute urease test in our laboratory we came across some interesting findings. In patients who had undergone treatment for Helicobacter with bismuth the biopsy specimen was positive on histological examination but negative on the urease test. In our study the sensitivity of the one minute urease test fell from $75 \%$ to $43 \%$. No change was seen in the placebo group. Although the organisms are still present, they lose their ability to produce urea after treatment. The urease test should not be used once treatment has begun.

If the treatment regimen has to be monitored, it is best to send the specimen for histological examination. GHAZALA HAQ
PMRC Research Centre,
JPMC, Karachi-35, Pakistan

\section{Opposition to 'Gut'}

SIR, - Apropos of the editor's note on Harold C Edwards, the first editor of Gut (Gut 1989; 30: 1659), in which Edwards's recollection of 'the vigorous discussion concerned with choosing a title and the opposition to "Gut" which was pretty strong' is cited, the readers of this journal may be interested and perhaps amused to know that when a group of young clinical investigators in gastroenterology met in New Haven in the early 'sixties to organise the Eastern Gut Club a vigorous discussion concerned with choosing a title arose, and the opposition to 'Gut' was also pretty strong. The opposition to that word by some finicky members of the east coast establishment collapsed, however, when it was pointed out that the recently published journal of the British Society of Gastroenterology was called Gut.

HENRY D JANOWITZ Mount Sinai School of Medicine New York NY 10029 \section{NOTE}

\section{Sir Francis Avery Jones BSG Research} Award 199

Applications are invited by the Education Committee of the British Society of Gastroenterology who will recommend to Council the recipient of the 1991 Award. Applications (15 copies) should include:

(1) a manuscript (2 A4 pages only) describing the work conducted;

(2) a bibliography of relevant personal publications;

(3) an outline of the proposed content of the lecture, including title;

(4) a written statement confirming that all or a substantial part of the work has been personally conducted in the United Kingdom or Eire.

The Award consists of a medal and a $£ 100$ prize. Entrants must be 40 years or less on 31 December 1991 but need not be a member of the BSG. The recipient will be required to deliver a 40 minute lecture at the Spring Meeting of the Society in Manchester in 1991. Applications ( 15 copies) should be made to: The Honorary Secretary, BSG, 3 St Andrew's Place, Regent's Park, London NW1 4LB by 1 December 1990. 